\title{
Occupational Stress - A Study With Reference To Selected Bank Employees in Chennai Region
}

\author{
${ }^{1}$ S Uma Mageswari, ${ }^{2}$ Dr N R V Prabhu \\ ${ }^{I}$ Research Scholar,Sathyabama University Jeppiar Nagar,Chennai - 600119 Tamil Nadu,India \\ ${ }^{2}$ Director AGNI Institute of Technology Old Mahabalipuram Road Thalambur Chennai - 600130 Tamil Nadu, \\ India
}

\begin{abstract}
Stress Management is drawing more and more attention nowadays, particularly in the corporate context. There is no such thing as a stress-free job. Everyone in his work is exposed to tension, frustration and anxiety as he gets through the duties assigned to him. In the interest of the individual customer, business world and the Government., Banks and Bank employees are playing a very important role for developing the Indian Economy. It is generally believed by the common man that employees of Banks may not experience stressors in their jobs when compared to other occupations. To test the validity of this belief the researcher had undertaken a study of "Occupational Stress - a study with reference to Bank Employees in Chennai" Comparative study with reference to the employees of Nationalized Banks, State Bank of India, Private sector Banks and the Cooperative sector Banks in Chennai
\end{abstract}

Key Words: Stress, Stressors, Organizational Stress, Coping strategies

\section{Introduction}

In today's economic environment of job insecurity, flatter organizations, and intense work pressures, there are quite a few managers who feel trapped where they are and such a feeling of being in a rut can turn into a persistent source of stress. If we feel frustrated in that job, we ought to do something about it. When we see successful People, we trend to assume that their careers have been smooth upward paths. It is not so, people who are seen to move up the management ladder step by step have no secret ticket or password. They simply work hard, watch for opportunities, await their turn, prepare and equip themselves for the bigger roles, and maintain a positive outlook on life. Second, it is not always necessary to switch jobs, to make our professional life more interesting and rewarding. Let us not presume that we have no power or means to improve the profile or lifestyle of the job, which we are now doing. Where there is a will, there is a way. If we have a good idea, we must preserve with it refuse to accept a negative response, and leave no stone unturned until we get it implemented. The sense of fulfillment and achievement which ensue, will elicit enduring satisfaction. What is more, a track record of such determination and indefatigable zeal cannot be ignored for too long, and the rewards will follow sooner or later. When we lack the ability and skill to lead with any situation, stress is bound to occur.

An ability to laugh is an excellent antidote to stress and anxiety. Laughter is a good medicine, a panacea for all seasons. 'You are not fully dressed, without a smile on your face' is an adage always to remember. The smile has been defined as a curve on the face which helps straighter tense issues in life, besides squaring up people problems which otherwise warrants going round in circles. Stress management involves three main types of intervention. They are stress prevention, employee training, and employee counseling programme. We ought to observe that there is a cyclical nature in the sequence of these interventions. Employee counseling programme is a voluntary and confidential service, which provides help to employees and their immediate families in dealing with their personal, or work - related issues.

\section{Statement Of The Problem}

Extreme stress results in marked changes in the person's behavior, attitude, motivations and cognition that there are inevitable consequences for the people with whom they interact. Such persons usually affect those around them by virtue of their inactivity and negativism, rather than by deviant or disruptive activity. The negative views of the past, present and future coupled with the feelings hopelessness, worthlessness, the lack of interest and motivation mean the employees can no longer fulfill the active roles that they were playing previously. The impact of this sort of behavior can be more easily identified in the Productive Industries rather than Service Industries.

In the interest of the individual customer, business world and the Government, banks and Bank employees are playing a very important role for developing the Indian Economy. Further Bank employees are considered to be a very important Human resource, where Banks serve better to the society and nation, the society and nation in turn develops. It is generally believed by the common man that employees of Banks may not experience stressors in their jobs when compared to other occupations. It is not so. To test the validity of this 
belief the researcher had undertaken a study on "Occupational Stress - a study with reference to Bank Employees in Chennai" Comparative study with reference to the employees of Nationalized Banks, State Bank of India. Private sector Banks and the Co-operative sector Banks in Chennai.

\section{Scope Of The Study}

A bank manager's duties mostly involve making decision of one land or another. It involves choosing a particular course of action after considering the possible alternatives. Whatever manager does, he does through making decision. As for as banks are concerned such decisions are vital for improving the customer services. Working group on customer services in banks appointed by the Government of India in 1977 said that 'bank users criticize and bankers themselves concede, the customer service rendered by banks leaves much to be desired. One of the greatest challenges facing the banking Industry today is the requirement of motivated, stressfree work force. When an employee joins a bank and becomes part of the multitude of the employed; the inevitable organization anomie takes over, devoid of recognition and individuality alienation and frustration in. In spite of the introduction of technology in banks, the banking industry in India will be labor intensive for many years to come. Therefore the attitudes and ethos of the working team have to be developed in a way whereby maximum synergy of man machine combination is to be achieved. The executives and employees should work in a team and develop team spirit in banks. This is the need of the hour.

A study of this type identifying the stress factors and analyzing the coping up strategies among bank employees will certainly help for developing HRD training and programmes in a big way. The present study deals with some important areas of stressors and stress management, comprising of occupational stressors and its causes and the coping techniques particularly on Bank employees of different sectors namely; The Indian Public sector Banks, State Bank of India, Indian Private sector Banks and the Indian co-operative sector Banks.

\section{Objectives Of The Study}

The present study mainly aims to study the occupational stress of bank employees. With this end in view, the following objectives are formulated.

- To identify and to examine the variables causing occupational stress among bank employees.

- To analyze the effect of such stress among bank employees.

- To identify the significant coping strategies adopted by bank employees.

- To make a comparative study among the employees of different bank groups and to identify the relationship between demographic variables and stressors as well as coping up strategies.

- To offer solutions based on the findings for the betterment of the area of 'Management of stress' in the Banking Sector.

\section{Hypothesis}

Keeping in view the wider theoretical framework and the above objectives of the study, the researcher has formulated the following hypotheses.

$>$ There is no significant difference among the three bank groups with respect to the stressors under study.

$>$ There is no significant difference among the three bank groups with respect to the various coping strategies.

$>$ There is no significant difference among the employees belonging to the different age pups, educational levels, designation, experience, income levels and other aspects as regards the various stressors.

$>$ There is no significant difference among the employees belonging to the different age groups, educational levels, designation, experience, income levels and other aspects as regards the various coping strategies.

\section{Significance Of The Study}

One of the most important resources is manpower. Hence to be effective, an executive needs the knowledge and understanding of human behavior and a high degree of social skill. Psychology and Psychologist have clear role to play in helping executives achieve these skills of understanding human behavior. Stress management in modem organizations has become a growing problem over the last decade Stress related illness and health problems are on the increase In every organization We find that 'stress' - costs the economy substantially more than industrial injury and more than industrial strikes (Marshall and Cooper. 1979).

Stress leads to physical disorders because the internal body system changes while trying to cope with stress. Stress over a prolonged time also leads to diseases of heart and other parts of the body system. Therefore it is important that stress, both on and off the job be kept at a low level so that most people may be able to tolerate without developing either emotional or physical disorders. In each and every organization, employees 
have to be kept fully satisfied, happy and motivated so that productivity, efficiency and performance will be at its peak level .By this employees may understand the organization and start functioning in an optimum efficiency One of the most significant way to achieve the organizational efficiency is to identify the reasons or causes of 'stressors' and the way to cope with it. Frequent studies on stress would help to uncover the shadow areas, so that steps can be initiated to minimize the effect of the determinant factors of 'stressors' and also help individuals and organizations evolve new and effective coping strategies. It is with is view the present study has been undertaken.

\section{Limitations Of The Study}

Though there are several areas in identifying the stressors. The present study is confined to the following areas:

$>$ The job and the related stressors.

$>$ Role and its related stressors.

$>$ Boss-subordinate relationship and the related stressors.

Decision making process and stress encountered by the respondents on account of it.

$>$ Familial factors and related stressors.

$>$ As human behavior changes with changing times, the respondents may express differently at different points of time. The limitation is always present in all studies on behavioral sciences.

$>$ Sex classification has not been taken up as most of the respondents are only male members.

\section{Methodology}

Commercial Banks in India have been classified into Public Sector Banks, private Sector Banks and Co-operative Sector Banks. Public sector banks are further subdivided into State Banks of India and its Associates and other Nationalized Banks. Private sector banks have been classified into private sector banks and foreign banks, in addition to this co-operative sector do operate banks under the classification 'Co-operative Banks'. Further for this study the researcher has taken three bank group i.e. nationalized banks, State Banks of India and its Associates, Indian Private Banks and the Co-operative Banks. Data were collected from the sample bank groups adopting convenience- sampling method. It is also identified that the number of employees in each branch of the private sector banks are also handful. Based on the total number of banks situated in Chennai under each category, the total sample size of 216 respondents comprising of 120 respondents belonging to Nationalized and SBI , 39 respondents from private banks and 57 respondents from cooperative banks were taken for the study .A structured questionnaire was prepared based on Likert's Scale. The collected data have been analyzed and interpreted using statistical tools such as weighted average mean, Correlation analysis, Regression Analysis. ANOVA, Critical ratio analysis and percentages

\section{Literature Review}

The term 'Stress' has come into wide use in behavior study only within the past two decades, Originating in the physical sciences, the term has the meaning of a force which, acting on a body, produces strain or deformation. Later stress has come to represent the bodily condition under strain. Both in the physical and biological sciences and behavioral study, the concept of stress meant an extreme condition, involving tension, perhaps damage and some form of resistance to the straining force. If one asks people about their stress and in particular how they know it exists - two general kinds of things are described: Firstly, there are experiences of mental discomfort often accompanied by feelings of not being able to cope, that things are falling apart, that one is not in control of oneself and one's situation or just a general unease that all is not well without any particular cause being apparent. Secondly they're the physiological manifestations of loss of appetite, sleeplessness, sweating and ulcers or other physical illnesses of various degrees. Physiological stress is described as the state of the organism following failure of the normal homeostatic regulatory mechanism of adaptation Stress is manifested through the symptoms of a General Adaptation Syndrome (Hans Selve. 1930).

The term stress in Engineering implies an inherent capacity to withstand stress. In Physics 'stress' is a force, which acts on a body to produce strain. In Physiology, stress refers to the changes in physiological function in response to the factors causing stress. In Psychology it refers to a state of the organism resulting from serve interaction with the environment. In Psycho - Physiology, the term 'stress' is that stimulates which imposes detectable strain that cannot be easily accommodated by the body and so presents itself as impaired health or behavior. The business person views stress as frustration or emotional tension; the air traffic controller sees it as a problem of alertness and concentration; the biochemist thinks it as a purely chemical event.

The concept of stress was first introduced in the life sciences by Hans Selye in 1936. It is a concept borrowed from the natural sciences. Derived from the Latin work 'Stringere', stress was popularly used in the seventeenth century to mean hardship, strain, adversity or affliction. It was used in the eighteenth and nineteenth centuries to denote force, pressure, strain or strong effort with reference to an object or person. The earliest and 
most important conceptualization of stress came from Seyle (1956). He observed an identical series of bio chemical changes in a number of organisms adapting to a variety of environmental conditions . He termed this series of changes as the 'General Adaptation Syndrome (GAS).

Beehr \& Newman, 1978; suggest that job stress contributes to health-related problems among workers and to organizational problems such as employee dissatisfaction, alienation, low productivity, absenteeism, and turnover. The concept of stress lacks precision in that it has been both broadly and narrowly defined, and treated as a stimulus, a response, an environmental characteristic, an individual attribute, and an interaction between an individual and his or her environment.

Cannon, 1929 has introduced the idea that environmental pressures can cause disease rather than just short time ill effects and that people have a natural tendency to resist such forces. Cannon studied the effects of stress on animals and people and, in particular, studied the fight-or-flight reaction (the physical reaction to either fight or flight when confronted with a stressor). He saw that people react physically to stressors: when confronted with a stressor, their physiological balance changes, for example, they show increased adrenaline secretions. Cannon described these individuals as being "under stress".

Cooper and Marshall 1976 are of the opinion that individuals in organizations are subject to conditions and occurrences that may result in psychological and/or physiological deviations from normal functioning. These deviations are seen as resulting from anticipated or missed opportunities, constraints on goal-directed behavior, or demands leading to important but uncertain outcomes. They are of the view that by occupational stress is meant environmental factors or stressors such as work overload, role conflict, role ambiguity, and poor working conditions associated with a particular job.

Holmes and Rahe 1967 based on Selye's work that changes in habits rather than the threat or meaning of critical events, is involved in the genesis of disease. The authors assumed that critical life events, regardless of their specific (e.g., positive or negative) quality, stimulate change that produces challenge to the organism. They suggest lifestyle changes can create stress; as the number of changes increase the risk of illness grows; stress can cause effect for as long as one year after the events

Kahn and Quinn, 1970 Role stress means anything about an organizational role that produces adverse consequences for the individual.

Lazarus, 1990 says that the so-called transactional stress models are concerned with the dynamics of the psychological mechanisms that underpin a stressful encounter. The term "transaction" implies that stress is neither in the person, nor in the environment, but in the dynamic transaction between the two. The transactional definition points to three important themes: a dynamic cognitive state, a disruption or imbalance in normal functioning, and the resolution of that disruption or imbalance. He opines that besides the obvious factors of office politics and colleague rivalry, stress can also be caused by lack of social support in difficult situations.

Mc Grath 1970, defines stress as a perceived substantial imbalance between demand and response capability, under conditions where failure to meet demand has important perceived consequences.

Murphy, 1995, said that common organizational and individual stressors could be classified into five groups:

(1) Organizational practices (performance reward systems, supervisory practices, Promotion opportunities)

(2) job/task features (workload, workplace, and autonomy)

(3) Organizational culture/climate (employee value, personal growth, integrity)

(4) Interpersonal relationships (supervisors, coworkers, customers), and

(5) Employee personal characteristics (personality traits, family relationships, coping skills).

\subsection{Stress In Different Sectors}

Jasmine (1987) conducted a study to compare the level of job-related stress among public and private sector blue-collar employees. A job stress scale developed by the author was administered to a sample of 120 blue-collar workers from public and 120 from private sector organizations. The analysis of the data revealed that role incumbents of public sector organization experienced significantly more stress than those of private sector organizations.

Sen (1981) in his study investigated the main role stresses experienced by employees in banks at different levels and the coping strategies adopted by them. Using the ORS Scale (Reek, 1983c,) Sen observed little difference between the scores in the three banks but he found interesting data about difference in role stresses at the organizational levels. Top level people obtained lower scores on role stagnations whereas clericals staff; obtained the highest score on this dimensions. Sen has interpreted this by observing that people at the lowest level felt that they were stagnating both individually; as well as role-wise However, this feeling decreased as people moved up in the hierarchy. 
Chaudhary (1990) examined the relationship between role stress and job satisfaction among bank officers. The main findings of the study were as follows

(a) Role erosion and resource inadequacy were experienced as dominant whereas role ambiguity and role expectation conflict as remote contributors of role stress among bank officers.

(b) No significant differences were observed between the two age groups on role stress dimensions.

(c) The overall indices of role stress and job satisfaction were found to be negatively correlated in higher as well as lower age groups of bank officers.

Mukherjee (1997) studied the relationship between organizational role stress, role efficacy, and organizational climate among banking professionals. The sample consisted of 71 managers which included 27 senior level and 44 junior level management personnel of a large banking organization. They concluded that junior level managers experienced higher stress on all the role stress dimensions as compared to senior level managers. Significant differences were observed between the two groups on the dimensions of inter-role distance, role overload, personal inadequacy and total role stress.

\section{Analysis And Intrepretation}

Stress is due to reactions of the body and mind to pressures associated with the work on hand. It may be physical or emotional. Each job carries some peculiar problems of its own. Bureaucratic practices and poor supervisory relationships often cause stress. An employee may also be frustrated if he feels that the present job does not provide any opportunity to prove his worth. It also appears that job satisfaction has a natural tendency to decline. A study on stress should embrace two important interacting Processes, namely, appraisal and coping. The appraisal process refers to the analysis of the determinants of stress (Stressors) and its effect on the individuals physical, psychological and behavioral well- being (Strain). The coping process is nothing but the different ways of dealing with stress. Thus, gaining a greater understanding of the processes related to stress has relevance for employees, organizations and society as a whole.

Table 1

Descriptive Statistics Of Stress Factors For All Sectors

\begin{tabular}{|c|c|c|c|c|c|c|}
\hline $\begin{array}{c}\text { STRESS } \\
\text { FACTORS }\end{array}$ & MEAN & MEDIAN & SD & $\begin{array}{c}\text { Population } \\
\text { Mean* }\end{array}$ & $\begin{array}{c}\text { 't' Value } \\
\text { Level of } \\
\text { Significance }\end{array}$ \\
\hline F1 & 8.93 & 9.00 & 3.7180 & 12.00 & -12.14 & 0.01 \\
\hline F2 & 28.47 & 26.50 & 18.0300 & 56.00 & -22.44 & 0.01 \\
\hline F4 & 9.76 & 7.00 & 7.7410 & 20.00 & -19.44 & 0.01 \\
\hline F5 & 14.17 & 14.50 & 6.0460 & 20.00 & -14.14 & 0.01 \\
\hline OVER ALL & 72.11 & 65.00 & 31.5700 & 120.00 & -22.29 & 0.01 \\
\hline
\end{tabular}

Classification of

Level of Stress

Low Level

F1

$$
\text { F }
$$

Moderate Level 8 to16

$$
<8
$$

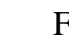

F3

F4 F5

$<10$

Over All

26 to52 10 to $20 \quad 10$ to20 6 to12 60 to120

$\begin{array}{lllll}>16 & >52 & >20 & >20 & >12\end{array}$


Table 1.1

Descriptive Statistics Of Stress Factors For Sector 1

\begin{tabular}{|c|c|c|c|c|c|c|}
\hline $\begin{array}{c}\text { STRESS } \\
\text { FACTORS }\end{array}$ & MEAN & MEDIAN & SD & $\begin{array}{c}\text { Population } \\
\text { Mean* }\end{array}$ & $\begin{array}{c}\text { Level of } \\
\text { Significance }\end{array}$ \\
\hline F1 Value & 9.00 & 4.2450 & 12.00 & -5.99 \\
\hline F2 & 29.21 & 28.00 & 18.4300 & 56.00 & -10.97 & -9.01 \\
\hline F3 & 9.05 & 7.00 & 9.1740 & 20.00 & -9.01 & 0.01 \\
\hline F4 & 13.37 & 16.00 & 9.2420 & 20.00 & -5.42 \\
\hline F5 & 10.68 & 11.00 & 7.9780 & 12.00 & -1.25 \\
\hline
\end{tabular}

Classification of

$\begin{array}{llllllrrr}\text { Level of Stress } & \text { F1 } & \text { F2 } & \text { F3 } & \text { F4 } & \text { F5 } & \text { Over All } & \\ \text { Low Level } & & <8 & <26 & <10 & <10 & <6 & <60 \\ \text { Moderate Level } & 8 \text { to16 } & 26 \text { to52 } & 10 \text { to } 20 & 10 \text { to } 20 & 6 \text { to12 } & 60 \text { to120 } & \\ \text { Low Level } & & >16 & >52 & >20 & >20 & >12 & >120\end{array}$

Table 1.2

Descriptive Statistics Of Stress Factors For Sector 2

\begin{tabular}{|c|c|c|c|c|c|c|}
\hline $\begin{array}{c}\text { STRESS } \\
\text { FACTORS }\end{array}$ & MEAN & MEDIAN & SD & $\begin{array}{c}\text { Population } \\
\text { Mean* }\end{array}$ & 't' Value & $\begin{array}{c}\text { Level of } \\
\text { Significance }\end{array}$ \\
\hline F1 & 9.92 & 9.00 & 3.7790 & 12.00 & -3.44 & 0.01 \\
\hline F2 & 27.77 & 22.00 & 16.8200 & 56.00 & -10.48 & 0.01 \\
\hline F3 & 10.46 & 7.00 & 6.0600 & 20.00 & -9.83 & 0.01 \\
\hline F4 & 15.46 & 16.00 & 3.9860 & 20.00 & -7.11 \\
\hline F5 & 8.31 & 9.00 & 4.7910 & 12.00 & -4.81 \\
\hline OVER ALL & 71.92 & 63.00 & 25.0400 & 120.00 & -11.99 & 0.01 \\
\hline
\end{tabular}

Classification of

\begin{tabular}{llllllrrr} 
Level of Stress & F1 & F2 & F3 & F4 & F5 & \multicolumn{2}{c}{ Over All } & \\
Low Level & & $<8$ & $<26$ & $<10$ & $<10$ & $<6$ & $<60$ \\
Moderate Level & 8 to16 & 26 to52 & 10 to 20 & 10 to 20 & 6 to12 & 60 to120 & \\
Low Level & & $>16$ & $>52$ & $>20$ & $>20$ & $>12$ & $>120$
\end{tabular}


Table 1.3

Descriptive Statistics Of Stress Factors For Sector 3

\begin{tabular}{|c|c|c|c|c|c|c|}
\multicolumn{1}{|c|}{$(\mathrm{N}=120)$} \\
\hline $\begin{array}{c}\text { STRESS } \\
\text { FACTORS }\end{array}$ & MEAN & MEDIAN & SD & $\begin{array}{c}\text { Population } \\
\text { Mean* }\end{array}$ & $\begin{array}{c}\text { Level of } \\
\text { Significance }\end{array}$ \\
\hline F1 & 8.75 & 8.50 & 3.3960 & 12.00 & -10.48 & 0.01 \\
\hline F2 & 28.35 & 24.50 & 18.3500 & 56.00 & -16.51 & 0.01 \\
\hline F3 & 9.87 & 7.50 & 7.5190 & 20.00 & -14.76 & 0.01 \\
\hline F4 & 14.12 & 13.50 & 4.4640 & 20.00 & -14.43 & 0.01 \\
\hline F5 & 11.62 & 11.50 & 4.3870 & 12.00 & -0.95 & 0.01 \\
\hline OVER ALL & 72.72 & 61.50 & 30.490 & 120.00 & -16.99 & 0.01 \\
\hline
\end{tabular}

Classification of

Level of Stress

Low Level

F1

\begin{tabular}{llcrr}
$\quad$ F2 & \multicolumn{1}{c}{ F3 } & F4 & F5 & \multicolumn{2}{c}{ over All } \\
$<8$ & $<26$ & $<10$ & $<10$ & $<6$ \\
26 to52 & 10 to 20 & 10 to 20 & 6 to 12 & 60 to 120 \\
$>16$ & $>52$ & $>20$ & $>20$ & $>12$
\end{tabular}

$<60$
$>120$

In general, the overall score of the stress is moderate for the respondents of all the three sectors. However, the various factors of stress did not have the same level of existence. Stress is more on factors 4 and 5 followed by factors 1 and 2 . At the other extreme, regarding the factor 3 , stress if less than the low mean value which indicates that stress is almost nil as far as factor 3 is concerned. (Table 1)

When the analysis was made for each sector, the stress scores of sector $1 \& 3$ are in line with the total scores, level Sector 2 indicates a different pattern of stress from the total stress scores. That is more stress on Factor 4, followed by Factors 1, 2 and 5. Regarding Factor 3 the stress is almost equal to the low score (Tables 1.1, $1.2 \& 1.3)$. The analysis indicates that the existence of stress in Sector 1 and 3 was in line with the total stress in banking sector in general. Sector 2 also had some similarity on some of the stress factors, namely Factor 1,2 and 4, which indicates that there is a consensus among the three sectors on these stress factors, more stress on Factor 4 and moderate on 1 and 2.

\section{Difference In Level Of Stress}

Significant difference was observed in the level of stress in factor 5 among the three sectors at 0.01 level of significance .Regarding all the other four factors there was no significant difference among the different banking sectors (Table 2). Different people respond to stress differently, some personalities are more inclined to respond negatively to stressors.

Table 2 Difference In Stressors Among The Three Sectors

Ho: There is no difference in perception of stressors among the respondents of three Sectors.

Test Used: ANOVA

\begin{tabular}{|c|c|c|c|c|c|c|}
\hline $\begin{array}{c}\text { STRESS } \\
\text { FACTORS }\end{array}$ & $\begin{array}{c}\text { Sources of } \\
\text { Variance }\end{array}$ & DF & $\begin{array}{l}\text { Sum of } \\
\text { Squares }\end{array}$ & Mean Squares & F Value & $\begin{array}{c}\text { Level of } \\
\text { Significance }\end{array}$ \\
\hline \multirow{3}{*}{ F1 } & Between & 2 & 47.43 & 23.71 & 1.73 & $\mathrm{NS}$ \\
\hline & Within & 213 & 29250.00 & 13.73 & & \\
\hline & Total & 215 & 29720.00 & & & \\
\hline \multirow{3}{*}{$\mathrm{F} 2$} & Between & 2 & 52.14 & 26.07 & 0.08 & NS \\
\hline & Within & 213 & 69860.00 & 328.00 & & \\
\hline & Total & 215 & 69910.00 & & & \\
\hline \multirow{3}{*}{ F3 } & Between & 2 & 49.30 & 24.65 & 0.41 & $\mathrm{NS}$ \\
\hline & Within & 213 & 12840.00 & 60.26 & & \\
\hline & Total & 215 & 12880.00 & & & \\
\hline \multirow{3}{*}{ F4 } & Between & 2 & 101.90 & 50.96 & 1.40 & NS \\
\hline & Within & 213 & 7758.00 & 36.52 & & \\
\hline & Total & 215 & 7860.00 & & & \\
\hline \multirow{3}{*}{ F5 } & Between & 2 & 324 & 162.30 & $5.14 * *$ & 0.01 \\
\hline & Within & 213 & 6727.00 & 31.58 & & \\
\hline & Total & 215 & 7051.00 & & & \\
\hline \multirow{3}{*}{ OVER ALL } & Between & 2 & 123.80 & 61.90 & 0.06 & NS \\
\hline & Within & 213 & 214200.00 & 1006.00 & & \\
\hline & Total & 215 & 214300.00 & & & \\
\hline
\end{tabular}


* Ho rejected at $\alpha-0.01$, NS - Not Significant

These include individuals with Type A personalities and Pessimists. Other such as Type B personalities and optimists, seem to respond more positively toward stressors (Schanbroeck,

Ganster \& Bemmerer 1994).

To explore the impact of personal variable on the feeling of stress the respondents were grouped based on personal variables as indicated in Table 6 and the statistical tool of simple regression was instrumented to identify the impact of these personal variables on stress. The analysis was carried at for the total respondents besides for the respondents of each sector. From the analysis it is clear that the demographic variables influence the stress significantly.

For all the three sectors the personal variable that influence the stress are listed below (Table 3)

All Sectors $(\mathrm{N}=216)$

$\mathrm{F} 1$ is influence by income

$\mathrm{F} 2$ is influence by length of service

$\mathrm{F} 3$ is influence by Education and length of service

F4 is influence by Age, Marital Status, Education and Designation

F5 is influence by Education, total service and service in banking sector

Over All - Length of service

Table 3

Simple Regression Results Of Personalvariables With Stress Factors Of Samples In All Sectors $\quad(\mathrm{N}=216)$

\begin{tabular}{|c|c|c|c|c|c|c|c|c|}
\hline RESULTS & Age & Sex & $\begin{array}{l}\text { Marital } \\
\text { Status }\end{array}$ & Education & $\begin{array}{c}\text { Designatio } \\
\mathrm{n}\end{array}$ & $\begin{array}{l}\text { Length of } \\
\text { Service }\end{array}$ & $\begin{array}{l}\text { Length of } \\
\text { Bank } \\
\text { Service }\end{array}$ & Income \\
\hline \multicolumn{9}{|c|}{ STRESS FACTOR 1} \\
\hline Constant & 9.7319 & 11.4700 & 10.4240 & 8.9547 & 7.9750 & 9.7890 & 7.9535 & 10.6140 \\
\hline Beta & -0.2498 & -2.1018 & -1.3788 & -0.0148 & -0.2000 & -0.2482 & 0.0466 & -0.5485 \\
\hline SE & 0.3105 & 0.6076 & 0.9126 & 0.2912 & 0.1924 & 0.1761 & 0.0263 & 0.2570 \\
\hline $\mathrm{R}$ & 0.0030 & 0.0530 & 0.0106 & 0.0000 & 0.0050 & 0.0092 & 0.0144 & 0.0208 \\
\hline Student ' $t$ ' & -0.80 & -3.46 & -1.51 & -0.45 & -1.04 & -1.41 & 1.77 & -2.13 \\
\hline \multicolumn{9}{|c|}{ STRESS FACTOR 2} \\
\hline Constant & 28.9470 & 31.1260 & 31.3940 & 30.6250 & 27.8750 & 18.5700 & 26.6240 & 29.9190 \\
\hline Beta & -0.1480 & -2.1965 & -2.6970 & -1.3133 & 0.1250 & 2.8633 & 0.8820 & -0.4714 \\
\hline $\mathrm{SE}$ & 1.5081 & 3.0245 & 4.4458 & 1.4092 & 0.9354 & 0.8355 & 0.1285 & 1.2590 \\
\hline $\mathrm{R}$ & 0.0000 & 0.0025 & 0.0017 & 0.0040 & 0.0001 & 0.0520 & 0.0022 & 0.0007 \\
\hline Student ' $\mathrm{t}$ ' & -0.10 & -0.73 & -0.61 & -0.93 & 0.13 & 3.4300 & 0.69 & -0.37 \\
\hline \multicolumn{9}{|c|}{ STRESS FACTOR 3} \\
\hline Constant & 8.7224 & 11.1330 & 12.6360 & 12.5890 & 8.1045 & 4.1559 & 8.7566 & 9.1746 \\
\hline Beta & 3.3246 & -1.1333 & -2.6515 & -1.7238 & 0.3473 & 1.6216 & 0.0481 & 0.1920 \\
\hline SE & 0.6471 & 1.2977 & 1.9016 & 0.5947 & 0.4009 & 0.3513 & 0.0551 & 0.5405 \\
\hline $\mathrm{R}$ & 0.0012 & 0.0036 & 0.0090 & 0.0378 & 0.0035 & 0.0905 & 0.0035 & 0.0006 \\
\hline Student ' $\mathrm{t}$ ' & 0.50 & -0.87 & -1.39 & $-2.90 * *$ & 0.87 & $4.62 * *$ & 0.87 & 0.36 \\
\hline \multicolumn{9}{|c|}{ STRESS FACTOR 4} \\
\hline Constant & 18.4220 & 13.0980 & 8.2576 & 16.5570 & 9.0348 & 13.7810 & 15.0410 & 15.9480 \\
\hline Beta & -1.3264 & 0.8842 & 5.4545 & -1.4588 & 1.0741 & 0.1118 & -0.4171 & -0.5802 \\
\hline SE & 0.4975 & 1.0136 & 1.4446 & 0.4628 & 0.3049 & 0.2876 & 0.0430 & 0.4204 \\
\hline $\mathrm{R}$ & 0.0321 & 0.0035 & 0.0625 & 0.0444 & 0.0548 & 0.0007 & 0.0044 & 0.0088 \\
\hline Student ' $\mathrm{t}$ ' & -2.67 & 0.87 & $3.78 * *$ & $-3.15 * *$ & $3.52 * *$ & 0.39 & -0.97 & -1.38 \\
\hline \multicolumn{9}{|c|}{ STRESS FACTOR 5} \\
\hline Constant & 10.4200 & 9.2175 & 10.3180 & 13.0520 & 10.2620 & 7.4958 & 7.7385 & 10.1020 \\
\hline Beta & 0.1114 & 1.2912 & 0.4273 & -1.3876 & 0.1080 & 0.9490 & 0.1430 & 0.2201 \\
\hline $\mathrm{SE}$ & 0.4789 & 0.9577 & 1.4128 & 0.4383 & 0.2970 & 0.2647 & 0.0396 & 0.3997 \\
\hline $\mathrm{R}$ & 0.0003 & 0.0084 & 0.0004 & 0.0447 & 0.0006 & 0.0567 & 0.0589 & 0.0014 \\
\hline Student ' $\mathrm{t}$ ' & 0.23 & 1.35 & 0.30 & $-3.17 * *$ & 0.36 & $3.59 * *$ & 3.66 & 0.55 \\
\hline \multicolumn{9}{|c|}{ OVER ALL } \\
\hline Constant & 76.2440 & 76.0460 & 73.0300 & 8.7780 & 63.2510 & 53.7910 & 66.1130 & 75.7570 \\
\hline Beta & -1.2881 & -3.2561 & -0.8485 & -5.8983 & 1.8545 & 5.2973 & 0.2862 & -1.1879 \\
\hline $\mathrm{SE}$ & 2.6392 & 5.2975 & 7.7907 & 2.4393 & 1.6330 & 1.4582 & 0.2244 & 2.2037 \\
\hline $\mathrm{R}$ & 0.0011 & 0.0018 & 0.0001 & 0.0266 & 0.0060 & 0.0581 & 0.0075 & 0.0014 \\
\hline Student ' $\mathrm{t}$ ' & -0.49 & -0.16 & -0.11 & -2.42 & 1.14 & $3.63 * *$ & 1.28 & -0.54 \\
\hline
\end{tabular}

*Significant at $5 \%$ level ** Significant at $1 \%$ level

Relationship Between Personal Variables And Stressors 
Ho: There is no difference in perception of OVERALL STRESS FACTORS among different group of respondents classified on personal variables

Test Used: ANOVA

Table 4

\begin{tabular}{|c|c|c|c|c|c|c|}
\hline $\begin{array}{c}\text { JOB } \\
\text { SATISFACTION } \\
\text { VARIABLES }\end{array}$ & $\begin{array}{l}\text { Sources } \\
\text { of } \\
\text { Variance }\end{array}$ & DF & $\begin{array}{l}\text { Sum of } \\
\text { Squares }\end{array}$ & $\begin{array}{c}\text { Mean } \\
\text { Squares }\end{array}$ & F Value & $\begin{array}{c}\text { Level of } \\
\text { Significance }\end{array}$ \\
\hline \multirow{3}{*}{ Age } & Between & 3 & 2579.0 & 859.60 & 0.86 & NS \\
\hline & Within & 212 & 211700.0 & 998.80 & & \\
\hline & Total & 215 & 214300.0 & & & \\
\hline \multirow{3}{*}{ Sex } & Between & 1 & 377.7 & 377.70 & 0.38 & NS \\
\hline & Within & 214 & 213900.0 & 997.70 & & \\
\hline & Total & 215 & 214300.0 & & & \\
\hline \multirow{3}{*}{ Marital Status } & Between & 1 & 11.8 & 11.88 & 0.01 & NS \\
\hline & Within & 214 & 21430.0 & 1001.00 & & \\
\hline & Total & 215 & 21430.0 & & & \\
\hline \multirow{3}{*}{$\begin{array}{c}\text { Educational } \\
\text { Qualification }\end{array}$} & Between & 3 & 18570.0 & 6190.00 & $6.70 * *$ & 0.01 \\
\hline & Within & 212 & 195800.0 & 923.40 & & \\
\hline & Total & 215 & 214300.0 & & & \\
\hline \multirow{3}{*}{ Designation } & Between & 5 & 44730.0 & 8945.00 & $11.08 * *$ & 0.01 \\
\hline & Within & 210 & 169600.0 & 807.60 & & \\
\hline & Total & 215 & 214300.0 & & & \\
\hline \multirow{3}{*}{$\begin{array}{l}\text { Period of service } \\
\text { in Parent Position }\end{array}$} & Between & 5 & 1860.0 & 3773.00 & $4.05^{* *}$ & 0.01 \\
\hline & Within & 210 & 195500.0 & 930.80 & & \\
\hline & Total & 215 & 214300.0 & & & \\
\hline \multirow{3}{*}{ Income } & Between & 4 & 1402.0 & 350.50 & 0.35 & NS \\
\hline & Within & 211 & 212900.0 & 1009.00 & & \\
\hline & Total & 215 & 214300.0 & & & \\
\hline
\end{tabular}

* Ho rejected at $\alpha-0.05$, ** Ho rejected at $\alpha-0.01$; NS - Not Significant

Among the various factor of stress, difference was observed with regard to most of the factors among the respondents of the three sectors at 0.01 and 0.05 levels of significance. It may be concluded that personal variable has an impact on stress considerably. Also the degree of impact varies across the sector. Most influencing personal variables are experience and designation followed by education income and age it indicates that older employees at high level, with more experience feel more stress than the other group. It is interesting to note that employees of higher income group have more stress, where as the lower income group has not.

Correlation Between Job Satisfaction And Stress Factors For All Sectors

$(\mathrm{N}=216)$

Table 5

\begin{tabular}{|c|c|c|c|c|c|c|}
\hline \multirow{2}{*}{$\begin{array}{c}\text { JOB SATISFACTION } \\
\text { VARIABLES }\end{array}$} & \multicolumn{6}{|c|}{ STRESS FACTORS } \\
\hline & F1 & $\mathrm{F} 2$ & F3 & $\mathrm{F} 4$ & F5 & OVER ALL \\
\hline Salary & -0.0438 & -0.0402 & 0.2362 & 0.0210 & 0.0043 & 0.0346 \\
\hline $\begin{array}{l}\text { Good Relationship with } \\
\text { Other Employees }\end{array}$ & -0.1033 & -0.1510 & -0.0818 & -0.2460 & -0.0140 & -0.1681 \\
\hline Working Conditions & -0.0742 & -0.2867 & -0.1360 & -0.1472 & -0.2569 & -0.2811 \\
\hline $\begin{array}{l}\text { Opportunities for } \\
\text { Promotion }\end{array}$ & 0.0023 & -0.2284 & -0.0910 & -0.1258 & -0.1925 & -0.2115 \\
\hline $\begin{array}{l}\text { Recognition in the } \\
\text { Organization }\end{array}$ & -0.0431 & -0.2180 & -0.2166 & -0.2045 & -0.1732 & -0.2533 \\
\hline Freedom of Work & -0.1626 & -0.3211 & -0.2318 & 0.0047 & -0.2408 & -0.3021 \\
\hline Nature of Job & 0.0157 & -0.1603 & -0.1128 & 0.0683 & -0.2001 & -0.1406 \\
\hline $\begin{array}{c}\text { Personal Need Properly } \\
\text { Looked After }\end{array}$ & -0.0972 & -0.2847 & -0.0369 & -0.1478 & -0.2333 & -0.2537 \\
\hline $\begin{array}{l}\text { Working here will have } \\
\text { social Status }\end{array}$ & -0.0943 & -0.2123 & -0.1177 & 0.0232 & 0.0716 & -0.1438 \\
\hline $\begin{array}{c}\text { TOTAL JOB } \\
\text { SATISFACTION }\end{array}$ & -0.1059 & -0.3669 & -0.1589 & -0.1399 & -0.2483 & -0.3328 \\
\hline
\end{tabular}


There exists a negative significant relationship between employees' opinion on stress and their job satisfaction. However, the correlation coefficient is low. This indicates that employees are more satisfied on their job when the stress is less. Likewise, they are dissatisfied when there is more stress.

\section{Coping Strategies}

Seven coping strategies developed by Deve and Guest (1989) are incorporated in this study

to identify the coping strategy used by the respondents

Relaxation Technique (RT),

Strategies for preparation (SOP),

Utilization of Home resources (UHR),

Distraction techniques (DT),

Rational Task Oriented Behavior (RTOB),

Passive Attempts (PA) and

Emotional relief (ER)

Table 6

Descriptive Stat Istics Of Coping Styles For All Sectors

\begin{tabular}{|c|c|c|c|c|c|}
\hline COPING STYLES & MEAN & MEDIAN & SD & $\begin{array}{c}\text { Population } \\
\text { Mean* }\end{array}$ & 't' Value \\
\hline RTOB & 1.8470 & 4 & 1.2010 & -26.35 & 0.01 \\
\hline ER & 2.1250 & 1 & 1.2490 & -15.60 & 0.01 \\
\hline SOP & 1.2780 & 7 & 1.3070 & -53.10 & 0.01 \\
\hline DT & 1.6390 & 5 & 1.1370 & -30.52 & 0.01 \\
\hline RT & 1.8610 & 3 & 1.1120 & -28.27 & 0.01 \\
\hline UHR & 1.9170 & 2 & 1.2470 & -24.55 & 0.01 \\
\hline PA & 1.4310 & 6 & 1.2810 & -52.42 & 0.01 \\
\hline
\end{tabular}

$(\mathrm{N}-216)$

* Rank is computed on the basis the basis of Mean scores

\section{Major Findings}

A study conducted by 'Fortune' magazine reveals the difference between successful and unsuccessful executives- the stability under pressure - the unique characteristic that makes them reach the top. This stability under pressure refers to management stress which is required in today's world. Optimum Stress is absolutely necessary; since, without stress complacency develops. People normally work well under pressure - with set target dates and deadlines individual success and organizational achievement are possible through optimum stress. When the limit exceeds, it endangers a person. Imagine the situations where there are no fixed working hours, no deadlines for the tasks to be completed, no annual budget for the organizations. There will be no charm in it. People will come as they like and a sense of laziness develops. At the same time, when the persons overstretch themselves, they experience all sorts of symptoms - be it hypertension, headache, acidity, etc due to stress. The former is called ROSS (Rust Our Stress Syndrome) and the latter is called BOSS (Burn Out Stress Syndrome). Both are bad and they cause considerable harm to the people experiencing it.

The present study is a modest attempt to identify the stress factors (stressors) and to examine the coping strategies among bank employees of different sectors. From the forgoing chapters, the researchers consolidates the important observations recorded in the study in the form of major findings and draws conclusions that world enable one to make valid suggestions for toning the stress management strategies in the banking sector.

1. In general, the overall score of the stress is moderate in all the three sectors as expressed by majority of the respondents. Among the various sectors, the respondents of the private banks showed a pattern of stress different from the scores of all other respondents.

2. 'Experience' is a major contributory cause of difference in perception of stress when respondents are classified under different groups based on personal variables. It has the maximum discriminating power also. Employees with more experience expressed more stress compared to employees with less service. It may be due to increase in responsibility with an increase in the length of service. Like 'experience', 
personal variables 'designation' and 'income' also influence the perception of stress. It is interesting to note that people getting more income felt more stress than the other groups.

3. A significant, but negative relationship is observed between stress and job satisfaction which indicates that satisfied employees expressed low stress compared to the dissatisfied employees. Also, except the factor 'recognition' all other factors of job satisfaction are influenced by stressors.

4. With regard to coping strategies there exists homogeneity among the respondents within the sector. Most of the respondents preferred 'Passive Attempts' and 'Emotional Relief strategies in managing stress. Some of the respondents viewed 'Rational Task Oriented \& behavior to cope with stress.

Stress is not always bad. A certain amount of stress is a positive and pleasurable thing. It leads to productivity in the human race. Hence, effective stress management does not always mean minimizing or eliminating stress. It is to keep the stress at the optimal level. Though the overall stress is moderate at present, it could be further shifted to optimum level by giving special attention to the stressors, managerial decision policies and job contents. Managerial policies in which the stress is high at present may be changed in relation to the expectations of the employees. Likewise, job contents - the low stressor at present - may be redesigned to make the job more interesting and challenging. In private banks, desired level of stress could be infused by paying attention to role factors in addition to managerial and job factors. Necessary steps may be taken to influence the level of stress, which exists among certain group of employees. To specify, management should pay attention to employees with more experience. Similarly management should attempt to satisfy people at the top level, who experience 'dis stress'. Training on coping strategies may be arranged for certain groups of employees who are older or who have higher qualifications, since they not only differ in the perception of stressors but also in the coping strategies, by making them recognize the appropriate coping strategies, stress could be proactively reduced.

\section{Conclusion}

To conclude, stress is like electric power. It can make a bulb light up and provide brilliant illumination. However if the voltage is higher than what the bulb can take, it can burn out the bulb. Individuals have to effectively act when stress is properly channelized resulting in the feeling of challenge, high satisfaction in the job, creativity, effectiveness better adjustment to work and life.

\section{References}

[1]. Beehr, T. A., \& Newman, J. E. Job stress, employee health, and organizational effectiveness: A facet analysis, model and literature review. Personnel Psychology, 1978, 31, 665-699.

[2]. Cannon, W. B. (1929). Bodily Changes in Pain, Hunger, Fear and Rage: an Account of Recent Research into the Function of Emotional Excitement, 2nd ed.New York: Appleton.

[3]. Chaudhary. A 'A study of relationship between job satisfaction and role stress of bank officers. L'npublished b1.A. Dissertation, Department of Psychology, University of Rajasthan, Jaipur, 1990

[4]. Cooper, C. L., \& Marshall, J. Occupational sources of stress: A review of the literature relating to coronary heart disease and mental ill health. Journal of Occupational Psychology, 1976, 49, 11-28.

[5]. Holmes, T H and Rahe, R H, (1967). The social readjustment rating scale. Journal of Psychosomatic Research, 11, pp. 213-218.

[6]. Jasmine, R A comparative study of private and public sector blue -collar employees on job related stress. Unpublished M.Phil dissertation Calicut University, Calicut. 1987

[7]. Kahn, R.L., \& Quinn, R.P. (1970). Role stress: A framework for analysis, In A. McLean (Ed.), Occupational mental health, New York: Wiley.

[8]. Lazarus, R.S. (1990). Theory based stress measurement. Psychological Inquiry, 1, 3-13.

[9]. McGrath, J.E. (1970). Major methodological issues. In J.E McGrath (Ed.), Social and psychological factors in stress (pp. 19 - 49). New York: Holt, Rineheart \& Winston.

[10]. Mukharjee, D. Study of role stress and role efficacy in relation to organization restructing: The case of SBI unpublished MBA dissertation, Indira Gandhi National Open University, New Delhil.1997.

[11]. Murphy, L. R. (1995), managing job stress - An employee assistance/human resource management partnership, Personnel Review, 24(1): 41-50

[12]. Selye. H "The Stress of Life New York: Mc. Graw - Hill. 1956.

[13]. Sen. P.C. 'A study of personal and organizational correlated of Role Stress and coping strategies in some public sector Banks' Ph.D. Thesis, Gujarat University, Ahmedabad, 1981. 